\begin{tabular}{c} 
KONSTAN \\
JURNAL FISIKA DAN PENDIDIKAN FISIKA \\
$\begin{array}{r}\text { Volume 6, Nomor 2, Desember 2021 } \\
\text { E-ISSN : 2460-9129 dan P-ISSN : 2460-9110 } \\
\text { http://jurnalkonstan.ac.id/index.php/jurnal }\end{array}$ \\
\hline
\end{tabular}

\title{
Literatur Review Pengaruh Pembelajaran Berbasis Kecakapan Hidup (Life skill) Terhadap Hasil Belajar Fisika Peserta Didik
}

\author{
Rif'il Husniyah ${ }^{1}$, Asrizal $^{2}$, Usmeldi $^{2}$ \\ ${ }^{1}$ Mahasiswa Program Studi Magister Pendidikan Fisika, Universitas Negeri Padang \\ ${ }^{2}$ Dosen Program Studi Magister Pendidikan Fisika, Universitas Negeri Padang \\ Jalan Prof. Dr. Hamka, Air Tawar, Padang \\ *E-mail korespondensi: husniyahrifil26@gmail.com
}

\begin{abstract}
Info Artikel: Abstract
Dikirim:

08 Sep 2021

Revisi:

15 Sep 2021

Diterima:

11 Okt 2021

\section{Kata Kunci:}

Literatur Review, Pembelajaran

Berbasis Life skill,

Hasil Belajar

Fisika

Tantangan abad 21 menuntut peserta didik agar mampu menyesuaikan diri dengan perkembangan teknologi. Pembelajaran berbasis kecakapan hidup (life skill) adalah salah satu solusi yang dapat digunakan oleh pendidik untuk menghadapi tantangan abad 21 tersebut. Pembelajaran berbasis kecakapan hidup merupakan pembelajaran yang menanamkan nilai-nilai kehidupan kepada peserta didik agar mampu dan terampil dalam menghadapi permasalahan kehidupan dan menemukan solusinya. Penelitian ini merupakan penelitian literatur review yaitu dengan merangkum dan mereview beberapa penelitian yang telah dilakukan sebelumnya dengan tujuan untuk mendeskripsikan dan menginterpretasikan data yang diperoleh terkait pengaruh pembelajaran berbasis kecakapan hidup terhadap hasil belajar fisika peserta didik. Dari hasil pencarian literatur diperoleh lima buah artikel yang terkait tentang pembelajaran berbasis kecakapan hidup terhadap hasil belajar fisika. Dari hasil analisis literatur yang telah dilakukan diperoleh rata-rata hasil belajar pada aspek pengetahuan (kognitif) sebesar 71,88. Pada aspek sikap (afektif) nilai rata-rata yang diperoleh sebesar 66,05 dan nilai rata-rata pada aspek keterampilan (psikomotor) sebesar 66,70. Berdasarkan hal tersebut dapat dinyatakan bahwa pembelajaran berbasis kecakapan hidup memiliki pengaruh yang efektif pada hasil belajar (pengetahuan, sikap, dan keterampilan) fisika peserta didik.
\end{abstract}

(C) 2021 Universitas Islam Negeri Mataram

\section{PENDAHULUAN}

Pendidikan abad 21 menuntut peserta didik untuk memiliki kecakapan hidup (life skill). Tujuannya agar mampu beradaptasi dengan perkembangan zaman yang sarat akan teknologi. Pendidikan abad 21 dapat tercapai apabila memadukan antara kecakapan pengetahuan, sikap, keterampilan dengan penguasaan terhadap teknologi informasi dan komunikasi pada pembelajaran di Sekolah. Selain itu peserta didik harus memiliki keterampilan berfikir kreatif (creative thinking), berfikir kritis dan pemecahan masalah (critical thinking and problem solving), berkomunikasi (communication) dan berkolaborasi (collaboration) [1]. Hal ini mengakibatkan peserta didik harus mengembangkan keterampilannya baik hard skill maupun soft skill pada proses pembelajaran [2]. Keterampilan tersebut dapat terwujud apabila pada pembelajaran menerapkan empat pilar pendidikan oleh UNESCO yaitu learning to know, learning to do, learning to be, learning to life together. 
Tujuan pendidikan abad 21 sejalan dengan Undang-undang Nomor 20 tahun 2003 tentang sistem pendidikan nasional yaitu untuk mengembangkan potensi peserta didik agar menjadi manusia yang beriman dan bertakwa kepada Tuhan Yang Maha Esa, berakhlak mulia, sehat, berilmu, cakap, kreatif, mandiri dan bertanggung jawab. Sehingga lahirlah lulusan pendidikan yang kompeten dan mampu bersaing diabad 21 [3]. Hal ini dapat diwujudkan apabila pembelajaran bersifat student center dan komunikatif [4]. Peserta didik sebagai subjek yang memiliki kemampuan mencari, mengolah, mengkontruksi dan menggunakan pengetahuan [5]

Pada hakikatnya tuntutan pendidikan abad 21 sudah sesuai dengan kurikulum 2103. Seperti halnya keterampilan abad 21, pendekatan saintifik dan penilaian autentik yang sudah ada pada kurikulum 2013 [6]. Pendekatan saintifik merupakan pembelajaran yang dilakukan dengan prosedur $5 \mathrm{M}$ yaitu mengamati, menanya, mengeksplorasi/mengumpulkan, mengasosiasi dan mengkomunikasikan [7]. Adapun penilaian autentik merupakan penilaian yang mengukur proses hasil belajar peserta didik. Penilaian autentik dapat mengungkapkan perkembangan kemampuan peserta didik [8].

Namun, implementasi kurikulum 2013 masih belum optimal di lapangan khususnya pada pembelajaran fisika[9]. Hal ini dapat dilihat dari penelitian-penelitian yang telah dilakukan sebelumnya. Pertama pembelajaran fisika masih menggunakan pendekatan konvensional [10]. Kedua, peserta didik belum terlibat aktif dalam kegiatan pembelajaran [11]. Ketiga pada proses pembelajaran masih menggunakan metode ceramah [12]. Dari pemaparan hasil-hasil penelitian ini dapat diketahui bahwa terjadi kesenjangan antara harapan dengan kenyataan yang terjadi.

Berdasarkan realita tersebut salah satu solusi yang dapat dijadikan sebagai alternatif adalah menggunakan pembelajaran berbasis kecakapan hidup (life skill). Kecakapan hidup merupakan kemampuan peserta didik dalam menghadapi permasalahan kehidupan. Tujuannya mengaktualisasikan potensi peserta didik agar dapat mencari solusi dari permasalahan hidup yang dihadapainya [13]. Kecakapan hidup dapat dipilah menjadi kecakapan mengenal diri sendiri, kecakapan berfikir rasional, kecakapan sosial, kecakapan akademik, dan kecakapan vokasional. Pembelajaran berbasis kecakapan hidup merupakan bekal dasar dan latihan kepada peserta didik tentang nilai-nilai kehidupan agar terampil menjaga kehidupannya [14]. Dengan adanya pembelajaran berbasis kecakapan hidup, peserta didik dapat bersaing dalam menghadapi kehidupan masa yang akan datang.

Keberhasilan pembelajaran berbasis kecakapan hidup dapat diamati melalui hasil belajar. Hasil belajar merupakan tingkat keberhasilan peserta didik berdasarkan pengalaman yang telah dilaluinya [15]. Selain itu untuk menentukan keberhasilan proses belajar mengajar dapat dilihat langsung dari hasil belajar peserta didik [16]. Pembelajaran berbasis kecakapan hidup dapat meningkatkan hasil belajar peserta didik [17]. Selain itu, pembelajaran lebih efektif dari segi waktu maupun ketercapaian kompetensi peserta didik [18]. Kelebihan lainnya yaitu dapat meningkatkan kecakapan vokasional peserta didik. Kemudian dapat meningkatkan kecakapan kesadaran diri dan kecakapan sosial peserta didik. Dengan adanya pembelajaran berbasis kecakapan hidup, peserta didik memiliki keunggulan yaitu terampil dalam kecakapan hidup dan menguasai komptensi pengetahuan, sikap dan keterampilan. Berdasarkan pemaparan tersebut, peneliti melakukan analisis literatur review untuk mengetahui pengaruh penggunaan pembelajaran berbasis kecakapan hidup (life skill) terhadap hasil belajar fisika peserta didik

\section{METODE PENELITIAN}

Penelitian ini merupakan studi literature yaitu dengan merangkum dan mereview beberapa penelitian yang pernah dilakukan dengan tujuan untuk mendeskripsikan serta menginterpretasikan informasi yang relevan terkait dengan penerapan pembelajaran berbasis life skill terhadap hasil belajar peserta didik yaitu ranah kognitif, afektif dan psikomotorik. Dari hasil seleksi artikel yang dilakukan berdasarkan tahun publikasi, tipe paper dan kesesuaian judul diperoleh jumlah artikel yang akan dianalisa adalah 5 buah artikel yang terdapat pada tabel 1. Setiap Artikel diberi kode R1, R2, R3, R4 dan R5. 
Tabel 1. Judul dan Sumber Artikel

\begin{tabular}{cl}
\hline Kode & \multicolumn{1}{c}{ Sumber Artikel } \\
\hline R1 & Widiastutik Wiwik Ayu, 2014 \\
R2 & Poniman, 2016 \\
R3 & Purwanti Ayu Indah, 2016 \\
R4 & Adepradana Cintopa Satria dan Ahmad Harjono, 2018 \\
R5 & Bahriah Evi Sapinatul, 2016 \\
\hline
\end{tabular}

Hasil belajar yang terdapat pada artikel yang direview akan dikelompokkan menjadi aspek pengetahuan, sikap dan keterampilan. Sehingga akan diperoleh nilai rata-rata pada masing-masing aspek. Nilai rata-rata yang diperoleh pada masing-masing aspek akan dikelompokkan berdasarkan pada kriteria skor pada tabel 2.

Tabel 2. Kriteria Skor

\begin{tabular}{cc}
\hline Rentang Nilai & Kategori \\
\hline $81-100$ & Sangat Baik \\
\hline $61-80$ & Baik \\
\hline $41-60$ & Cukup \\
\hline $21-40$ & Kurang \\
\hline $0-20$ & Sangat Kurang \\
\hline
\end{tabular}

Sumber: Arikunto, 2007 [19]

\section{HASIL DAN PEMBAHASAN}

Artikel yang telah diperoleh berdasarkan pada tabel 1 memiliki pembahasan yang sama yaitu pengaruh pembelajaran life skill pada hasil belajar fisika peserta didik. Literatur pertama dilakukan oleh Widiastutik [17]. Metode penelitian yang Ia lakukan adalah Pretest Postest Control Group Design. Subjek penelitiannya adalah kelas XI IA 5 dan XI IA 6. Hasil belajar yang diteliti meliputi aspek pengetahuan, sikap dan keterampilan. Pada aspek pengetahuan diperoleh rata-rata thitung sebesar 4,50 $t_{\text {tabel }}$ adalalah 1,67, sehingga $t_{\text {hitung }}$ besar dari tabel. Pada aspek afektif (sikap) kelas eksperimen diperoleh rata-rata persentase sebesar 93 sedangkan untuk kelas kontrol sebesar $67 \mathrm{Hal}$ ini menunjukkan adanya perbedaan persentase sebesar $0,38 \%$ antara kelas eksperimen dan kontrol. Pada aspek keterampilan (psikomotorik) rata-rata persentase kelas eksperimen adalah 80,5 sedangkan untuk kelas kontrol sebesar 64, perbedaan persentase sebesar $0,25 \%$. Berdasarkan pemaparan data tersebut maka penggunaan pembelajaran berbasis life skill memiliki pengaruh terhadap hasil belajar fisika peserta didik.

Literatur kedua dilakukan oleh Poniman [18]. Penelitian yang ia lakukan merupakan penelitian tindakan kelas dengan subjek penelitian kelas XII IPA 1. Pada siklus pertama diperoleh rata-rata aspek pengetahuan sebesar 56, 2, aspek sikap sebesar 67,65 dan aspek keterampilan sebesar 61,66. Pada siklus kedua diperoleh nilai rata-rata pada aspek pengetahuan sebesar 58, 1, untuk aspek sikap sebesar 74,67 dan aspek keterampilan sebesar 55.88. Hal ini menunjukkan adanya peningkatan dari siklus pertama ke siklus kedua. Untuk aspek pengetahuan terjadi peningkatan sebesar $0,03 \%$, aspek sikap terjadi peningkatan sebesar $0,1 \%$ sedangkan pada aspek keterampilan terjadi penurunan sebesar $0,09 \%$. Berdasarkan paparan data tersebut terdapat pengaruh pembelajaran berbasis life skill terhadap aspek pengetahuan dan sikap peserta didik.

Literatur ketiga dilakukan oleh Purwanti [20]. Penelitian yang Ia lakukan merupakan deskriptif regresional dengan subjek penelitian kelas XII IPA SMA N 21 Makassar. Pada aspek pengetahuan diperoleh rata-rata sebesar 85,16, pada aspek sosial (sikap) sebesar 62,5 dan pada aspek vokasinonal (keterampilan) sebesar 55,7. Untuk aspek pengetahuan berada pada kategori tinggi begitu juga dengan vokasional dan sosial berada pada kategori tinggi.

Literatur ke empat dilakukan oleh Adepradana [21]. Penelitian yang Ia lakukan menggunakan metode Pretest Postest Experimental Control Group Design. Subjek penelitiannya adalah kelas IX A sebagai kelas exkperimen dan IX B sebagai kelas kontrol. Pada kecakapan akademik kelas 
eksperimen diperoleh nilai rata-rata sebesar 6,48 sedangkan pada kelas kontrol sebesar 5,06, sehingga terdapat perbedaan sebesar $0,28 \%$ antara kedua kelas tersebut. Pada kecakapan berfikir diperoleh rata-rata sebesar 7,51 dan 4,46 untuk kelas eksperimen dan kontrol, sehingga terdapat perbedaan 0,68\%. Rata-rata kecakapan vokasional sebesar 6,48 dan 5,80 untuk kelas eksperimen dan kontrol dengan perbedaan sebesar $0,12 \%$. Rata-rata kecakapan mengenal diri adalah 3, 75 dan 3,26 untuk kelas eksperimen dan kontrol dengan perbedaan sebesar $0,15 \%$.

Literatur kelima dilakukan oleh Evi Sapinatul Bahriah [22]. Penelitian yang Ia lakukan merupakan peneltian deskriptif dengan subjek penelitian kelas XI IPA 2. Pada kecakapan akademik diperoleh rata-rata sebesar 80,42. Pada kecakapan vokasional diperoleh rata-rata sebesar 73,73. Untuk kecakapan akademik berada pada kategori sangat baik. Kecakapan vokasional berada pada kategori baik. Hal ini menunjukkan pembelajaran life skill berpengaruh terhadap hasil belajar peserta didik.

Berdasarkan paparan data dari lima buah literatur yang telah direview dapat diperoleh kategori hasil belajar (kategori merujuk pada tabel 2). Untuk literatur pertama rata-rata hasil belajar adalah 86,75 , berada pada kategori sangat baik. Literatur kedua memiliki rata-rata hasil belajar sebesar 62,36, berada pada baik. Untuk literatur ketiga memiliki nilai rata-rata sebesar 67,78 berada pada kategori baik. Literatur keempat memiliki rata-rata sebesar 68,2 berada pada kategori baik. Dan literatur kelima sebesar 77,1 berada pada kategori baik. Dari rata-rata hasil belajar masing-masing literatur dapat dilihat bahwasanya yang memiliki pengaruh sangat baik berada pada literatur pertama, kemudian diikuti oleh literatur kedua (kategori baik), literatur ke empat (kategori baik), literatur ketiga (kategori baik) dan literatur kedua (kategori baik). Sedangkan untuk rata-rata nilai masingmasing aspek (pengetahuan, sikap dan keterampilan) yang dikelompokkan dari setiap literatur dapat dilihat pada gambar berikut.

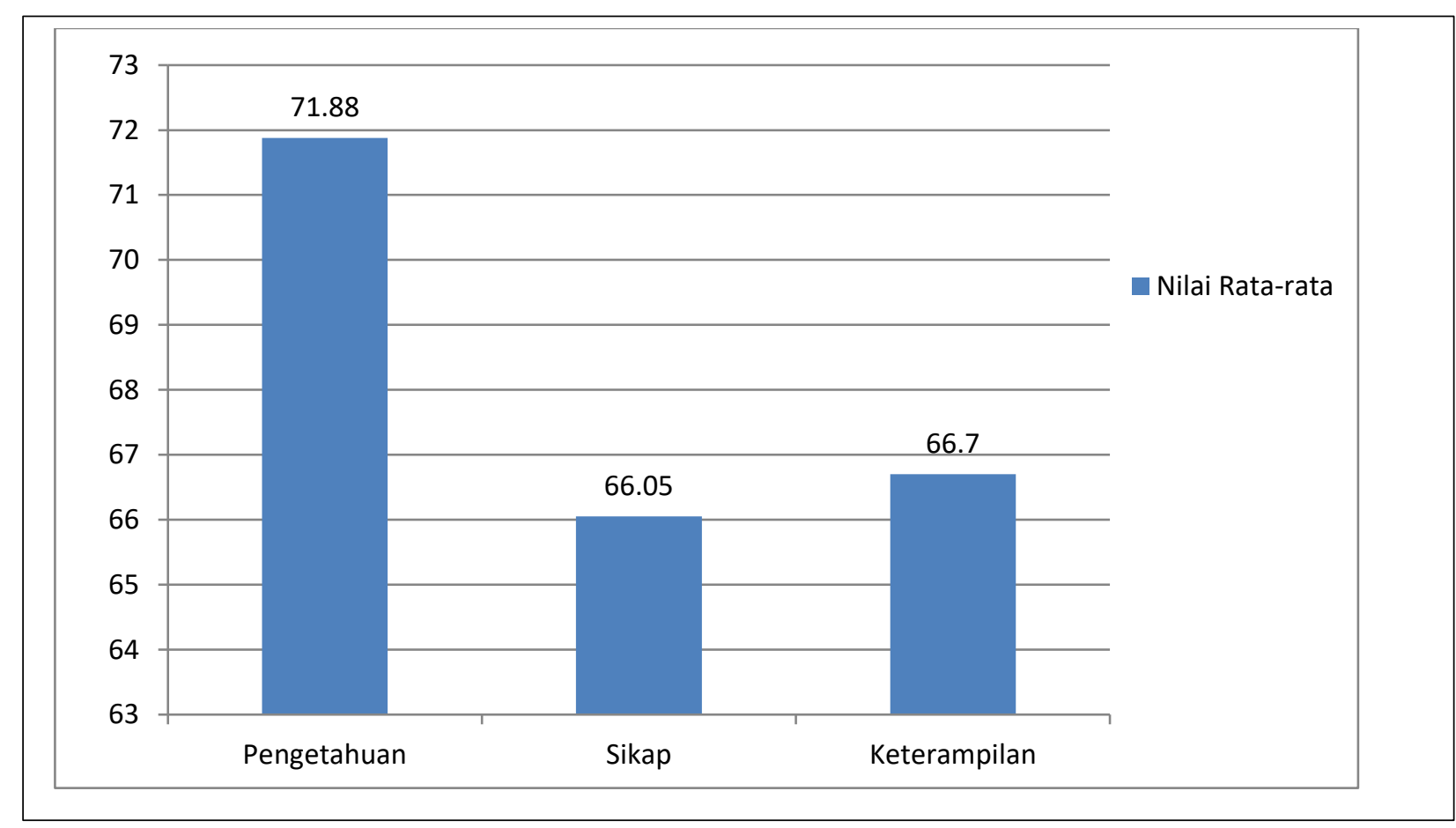

Gambar 1. Nilai rata-rata hasil belajar pada aspek pengetahuan, sikap dan keterampilan

Dari gambar 1 dapat dilihat dengan jelas bahwa lima buah artikel yang direview pada pembelajaran life skill memiliki pengaruh yang baik pada hasil belajar fisika peserta didik. Aspek pengetahuan memiliki nilai rata-rata dari ke lima literatur sebesar 71,88, aspek sikap sebesar 66,05 dan aspek keterampilan sebesar 66,7 berada pada kategori baik. Hal ini sesuai dengan penelitian yang telah dilakukan oleh Nazmi, bahwa penerapan pembelajaran berbasis life skill dapat meningkatkan keterampilan generik sains yang merupakan perpaduan antara pengetahuan sains dan keterampilan peserta didik [23]. Selain itu pembelajaran berbasis life skill dapat mempersiapkan peserta didik agar 
memiliki sikap dan kecakapan hidup sebagai bekal untuk kehidupannya [24]. Dengan adanya kecakapan hidup dalam pembelajaran memberikan kesempatan kepada setiap peserta didik untuk meningkatkan kompetensinya[25]. Karena kecakapan hidup memberikan bekal keterampilan yang praktis, terpakai, terkait dengan kebutuhan pasar kerja yang ada di masyarakat [26]. Jadi dengan adanya pembelajaran berbasis life skill peserta didik mampu meningkatkan prestasi belajar dan memiliki keberanian dalam menghadapi permasalahan kehidupan yang dihadapinya

\section{KESIMPULAN}

Berdasarkan hasil analisis literatur yang telah dilakukan dapat ditarik beberapa kesimpulan. Pertama pengaruh pembelajaran berbasis life skill terhadap aspek pengetahuan fisika peserta didik berada pada kategori baik. Kedua pengaruh pembelajaran berbasis life skill terhadap aspek sikap peserta didik berada pada kategori baik. Ketiga pengaruh pembelajaran berbasis life skill terhadap aspek keterampilan peserta didik berada pada kategori baik. Jadi pembelajaran berbasis life skill memiliki pengaruh yang efektif terhadap hasil belajar fisika peserta didik. Semoga pembelajaran berbasis life skill ini dapat diterapkan pada pembelajaran di sekolah agar peserta didik mampu menyesuaikan diri dengan perkembangan zaman dan mampu menghadapi segala permasalahan yang ada di dalam kehidupannya

\section{DAFTAR PUSTAKA}

[1] P21. "21 $1^{\text {st }}$ Century Skills, Education \& competitiveness, Washington DC, Partnership for 21 st Century Skills," 2008

[2] R. Septikasari, \& R. N. Frasandy, "Keterampilan 4C Abad 21 Dalam Pembelajaran Pendidikan Dasar," Jurnal Tarbiyah Al-Awlad, vol 3, no 2, pp. 107-117, 2018

[3] Asrizat, A, Ananda, \& Festiyed, "Effectiveness Of Adaptive Contextual Learning Model OF Integrated Science by Integrating Digital Age Literacy on Grade VIII Students," IOP Conferences, pp. 1-8, 2018.

[4] Asrizal, A, Ananda \& Suharsimin, “ The Development of Integrated Science Instructional Materials to Improve Student Digital Literacy In Scientific Approach, Jurnal Pendidikan IPA, vol 7, no 4, pp. 442-450, 2018.

[5] Usmeldi, R. Amini \& S. Trisna, "The Development of Research Base Learning Model With Science, Enviroment, Technology, And Society Approach To Improve Critical Thinking Of Students. Jurnal Pendidikan IPA, vol 6, no 2, pp. 318-325, 2017.

[6] K.. E, Murti, "Pendidikan Abad 21 dan Aplikasinya dalam Pembelajaran di SMK," 2018.

[7] Sufairoh, "Pendekatan Saintifik dan Model Pembelajaran Kurikulum 2013, Jurnal Pendidikan Profesional, vol 5 no 3, pp. 116-125, 2016.

[8] T. Rukmana \& Mundilarto, "Keterlaksaan Penilaian Autenik Mata Pelajaran Fisika SMA Negeri, Jurnal Inovasi Pendidikan IPA,” vol 2, no 1, pp. 111-121, 2016.

[9] Y. Andrian \& Rusman, "Implementasi Pembelajaran Abad 21 Dalam Kurikulum 2013," Jurnal Penelitian Ilmu Pendidikan, vol 12, no 1, pp. 14-23, 2019.

[10] A. Istyowati, S, Kusairi \& Handayanto, Analisis Pembelajaran dan Kesulitan Siswa SMA Kelas XI Terhadap Penguasaan Konsep Fisika. Prosiding Seminar Nasional UM Malang, pp. 237-243, 2017.

[11] R. Lestari, W, Ahdinirwanto \& Ashari, "Peningkatan Pemecahan Masalah Melalui Model Pembelajaran Cooperative integrated reading and composition (CIRC) pada SMP $\mathrm{N} 4$ Wadaslintang, Jurnal Radiasi, vol 4, no 2, pp. 178-181, 2013

[12] A. Fitriyah, \& A. Arief, "Penerapan Model Pembelajaran Kooperatif Tpe TAI untuk Meningkatkan Aktivitas Dan Hasil Belajar Siswa Kelas X, Jurnal Inovasi Pendidikan Fisika, vol 6, no 3, pp.

[13] Mujakir, "Pengembangan Life skill Dalam Pembelajaran Sains," Jurnal Ilmiah Didaktika, vol 13, no 1, pp. 1-13, 2012 
[14] S. Marwiyah, "Konsep Pendidikan Berbasis Kecakapan Hidup, Jurnal FALASIFA, vol 3 No 1, pp. 77-97, 2012.

[15] Wulandari, "Pengaruh Problem Base Learning Terhadap Hasil Belajar Ditinjau dari Motivasi Belajar PLC di SMK," Jurnal Pendidikan Vokasi, vol 3, pp. 178-180. 2013

[16] E. Qomaliyah, N. Sukib, \& I. N. Loka,'Pengaruh Model Pembelajaran Inquiry Terbimbing Terhadap Hasil Belajar, Jurnal Pijar MIPA, vol 11, no 2, pp. 105-109, 2016

[17] W. A. Widiastutik, "Pengaruh Pembelajaran Fisika Berbasis Life skill Terhadap Hasil Belajar Siswa Kelas XI SMA Negeri 9 Semarang," pp. 6-9, 2014

[18] Poniman, "Pembelajaran Fisika Berbasis Kompetensi Life skill Kelas XII IPA 1 Madrasah Aliyah Negeri 1 Lampung Selatan,"Jurnal Imiah Pendidikan Fisika Al Biruni, vol 5, no 1, 2016

[19] S. Arikunto, "Prosedur Penelitian Suatu Pendekatan Praktik," Jakarta: Rineka Cipta, 2007

[20] A. Y. Purwanti, "Pengaruh Pembelajaran Fisika Terhadap Kecakapan Vokasional dan Kecakapan Sosial Siswa Kelas XII IPA SMA Negeri 21 Makassar,” Jurnal Pendidikan Fisika, vol 3 no 1, 2016.

[21] C. S. Adepradana \& A. Harjono, "Pengaruh Advance Organizer berbasis Proyek Terhadap Kecakapan Hidup dan kemampuan analisis sintesi mata pelajaran Fisika Siswa," Konstan Jurnal Fisika dan Pendidikan Fisika, vol 3, no 1, 2018.

[22] E.S. Bahriah, S. Agung \& Yudiantino, "Analisis Life skill Siswa pada Aspek Spesific Life skills Dalam Pembelajaran Koloid Berbasis Proyek," Proseding Seminar Pendidikan IPA Pascasarjana UM, pp. 1120-1129, 2016.

[23] Nazmi, "Pengaruh Pembelajaran Life skill Terhadap Keterampilan Generik Sains Biologi Ditinjau Dari Self Regulation Peserta Didik Kelas X Di SMA 12 Bandar Lampung," 2018

[24] Mislaini, "Pendidikan dan Bimbingan Kecakapan Hidup (Life skill) Peserta Didik, Jurnal Ilmiah Pendidikan," vol 1 no 1, pp. 147-163, 2017.

[25] S.N. Cahyaningrum, "Hubungan Antara Life skill Siswa Dengan Hasil Belajar Praktikum Pengelasan di SMKN Trenggalek" Jurnal teknik mesin, 2013.

[26] Anwar, "Pendidikan kecakapan hidup (life skill education)," Bandung: alfabeta, 2006. 